\title{
Conversas a distância o cotidiano epistolar da Baronesa dos Três Serros no início do século XX (Rio de Janeiro/Pelotas-RS) ${ }^{*}$
}

\section{Distance conversations \\ epistolary daylife of Baroness of Three Hills in early XX ${ }^{\text {th }}$ Century}

(Rio de Janeiro/Pelotas-RS)

\author{
DÉBORA CLASEN DE PAULA \\ Mestre em História pela UNISINOS \\ Professora do Curso de Licenciatura Plena em História \\ Universidade Federal da Fronteira Sul (UFFS) - Erechim \\ Av. Dom João Hoffmann, 313, Bairro Fátima \\ CEP 99700-000 - Erechim - RS \\ debora.paula@uffs.edu.br; deboraclasen@hotmail.com
}

RESUMO 0 artigo visa apresentar a escrita epistolar de Amélia Hartley de Brito Antunes Maciel, Baronesa dos Três Serros. Dentre as 151 missivas escritas entre os anos de 1885 e 1918, a maior parte tinha como destinatária a filha mais velha Amélia Aníbal Hartley Maciel, mais conhecida como Sinhá. Ao estreitar os laços familiares pedindo e fornecendo notícias, Amélia informa sobre uma série de outros assuntos que nos permite perceber como era mantido o pacto epistolar. As correspondências revelam detalhes sobre o cotidiano da escrita, seus significados, o momento de feitura, sobre como, o quê, porquê e onde Amélia escrevia. Pode-se observar ainda, a forma como Amélia lia, respondia e organizava as missivas recebidas.

* Artigo recebido em: 16/01/2011. Aprovado em: 13/12/2011. 
Palavras-chave Baronesa dos Três Serros, cartas, escrita epistolar

ABSTRACT This article presents epistolary writings of Amélia Hartley de Brito Antunes Maciel, Broness of Three Hills. Among 151 letters from 1885 and 1918, most of them had her eldest daughter Amélia Anibal Hartley Maciel, called "sinhá", as addressee. By getting closer to her relatives through the use of written messages, Amélia provides information on many other subjects. That enables us to understand how epistolary agreement was maintained. The letters show details of day-to-day in writing, its meanings, the moment of writing, the subject, reasons, ways, and where Amélia used to write. One can see the way Amélia used to read, reply, and organize the letters she received.

Keywords Baroness of Three Hills, letters, epistolary writing

Era outono de 1899 quando Amélia, reunindo as duas últimas cartas enviadas pela filha, se preparava para respondê-las. O início de sua carta, e, posteriormente, as inúmeras outras que se seguiram, revelam que o que se tem em mãos é apenas parte de um diálogo maior. "A tua carta de 15, já foi respondida, e é provável, que n'esta dacta, esteja em teu poder". ${ }^{1}$

Amélia Hartley de Brito Antunes Maciel, Baronesa dos Três Serros, encontrava-se em Paquetá naquele mês de abril. Admirando as belezas da cidade como a "A tão decantada pedra da - Moreninha", ${ }^{2}$ lamentava-se por não poder contar com a presença da filha que se encontrava em Pelotas, "Coméço então a lembrar-me se poderás vir este inverno, ou se só no verão nos reuniremos!". 3

Esta separação entre mãe e filha propiciava a produção e a troca de cartas, recurso utilizado para estreitar o vínculo familiar prejudicado pela distância e pela ausência. ${ }^{4}$ Amélia e Sinhá se escreviam, e muito em determinados períodos. A escrita era interrompida quando havia o encontro das duas, seja porque Amélia viajava a Pelotas para junto da filha no verão, ou esta se deslocava para o Rio de Janeiro durante o inverno.

Pode-se dizer que Amélia era uma escrevente, que viveu na segunda metade do século XIX, e que se utilizava amplamente das palavras para se comu-

1 Carta da Baronesa. Paquetá, 17 de abril de 1899. As cartas da Baronesa compõem o acervo documental existente no Museu Municipal Parque da Baronesa em Pelotas/RS. Para este trabalho foi mantida a grafia original das cartas. Este artigo é parte do primeiro sub-capítulo de minha dissertação de mestrado. PAULA, Débora C. de. $D a$ mãe e amiga Amélia: cartas de uma baronesa para sua filha (Rio de Janeiro - Pelotas, na virada do século XX). São Leopoldo, Unisinos, 2008. (História, Dissertação de mestrado).

2 Carta da Baronesa. Paquetá, 17 de abril de 1899.

3 Carta da Baronesa. Paquetá, 17 de abril de 1899.

4 "Distância e ausência são, ainda hoje, motores para a efetivação do ato de escrever cartas, de se corresponder". BASTOS, Maria Helena Camara; CUNHA, Maria Teresa Santos e MIGNOT, Ana Chystina Venâncio. Laços de papel. In: Destinos das letras: história, educação e escrita epistolar. Passo Fundo: UPF, 2002. 
nicar. ${ }^{5}$ Suas cartas, em razão disso, se constituem em fonte importante para analise de como se dava a comunicação familiar na virada do século XX.

A Baronesa já era viúva quando voltou a estabelecer residência no Rio de Janeiro, sua terra natal, visitando Pelotas de maneira esporádica. 0 casamento com Aníbal Antunes Maciel, filho do coronel rio-grandino Aníbal Antunes Maciel ocorreu, de acordo com o Nobiliário Sul Riograndense, quando ela tinha pouco mais de 15 anos. ${ }^{6}$ Por meio desta fonte, sabemos ainda que ela havia nascido em dezembro de 1848 , sendo filha do Comendador João Diogo Hartley e de Isabel Fortunata de Brito.

Em agosto de 1864, Amélia e Aníbal se uniam em matrimônio, passando a residir em Pelotas numa propriedade presenteada pelo pai de Aníbal. 0 marido de Amélia, bacharel em Ciências Físicas e Matemáticas, ${ }^{7}$ se dedicou, ao longo da vida, à criação de gado para abastecer as charqueadas pelotenses, ainda rentáveis, apesar da competição cada vez mais acirrada com o charque platino. Todavia, o ano escolhido para o casamento não desfrutava de total tranqüilidade, sobretudo para os pecuaristas rio-grandenses com terras no Uruguai, como era o caso dos Antunes Maciel.

Aníbal foi "condecorado com a cruz de bronze pela campanha do Paraguai" guerra na qual tomou parte e teve que se retirar antes do término devido à "incommodos de saude". ${ }^{8}$ Além da guerra, participou da vida pública de Pelotas, tendo sido vice-presidente da Biblioteca Pública Pelotense e vereador da cidade, além de militar, juntamente com os demais homens da família, nas fileiras do Partido Liberal.

Por ter libertado seus escravos, encaminhou uma petição de título e, através do Decreto Imperial de 26 de julho de 1884, foi agraciado com o título

5 O termo escrevente é de Roland Barthes e foi criado para diferenciar do termo escritora. A (o) escrevente seria aquela (e) que usa a palavra para se comunicar, testemunhar, explicar sem a preocupação com a língua. BARTHES, Roland. Escritores e escreventes. In: Crítica e verdade. São Paulo: Perspectiva, 1982, p.31-39.

6 É interessante colocar que este Nobiliário Sul Riograndense utilizado na consulta pertencia à neta dos Barões, Zilda Maciel de Abreu e Silva e foi doado ao Museu. O livro possui anotações feitas à caneta nas folhas dedicadas ao Barão de Três Serros, "meu avô materno", "vovô Aníbal". Uma destas anotações, provavelmente feitas por Zilda, foi importante para identificar quem era a filha que a baronesa nas cartas chamava sempre pelo apelido. CARVALHO, Mario Teixeira de. Nobiliário Sul-Riograndense. Porto Alegre: Of. Graf. da Livraria do Globo,1937, p.336-339.

7 Conforme o Nobiliário Sul-Riograndense Aníbal era Bacharel em Ciências Jurídicas e Sociais, informação considerada equivocada por José Francisco de Assumpção Santos que o coloca como bacharel em Ciências Físicas e Matemáticas (Engenheiro). SANTOS, José Francisco de Assumpção. Uma linhagem Sul Rio-Grandense os "Antunes Maciel". Instituto Genealógico Brasileiro: Rio de Janeiro, 1957. A nota de falecimento publicada no Jornal Diário de Pelotas informa somente que Aníbal havia sido "engenheiro militar". Diário de Pelotas. Pelotas, 22 de março de 1887, n.217, p.01.

8 Diário de Pelotas. Pelotas, 22 de março de 1887, n.217, p.01. 
de Barão dos Três Serros. ${ }^{9}$ Entretanto, não era o único em sua família a alcançar título de nobreza uma vez que era irmão da Baronesa de Arroio Grande, tio da Baronesa de Sobral e primo do Barão de São Luis e do Barão de Cacequi. ${ }^{10}$

Porém, três anos após a concessão do baronato, Aníbal falece, deixando Amélia, aos 38 anos de idade, com oito filhos para criar; a mais velha, Amélia, com 18 anos, e o mais novo, Edmundo, com um ano e 10 meses.

No inventário, consta entre os bens arrolados, a propriedade das fazendas São Pedro, do Pavão, do Paraíso, e a de Três Serros no Brasil e, também, as fazendas Salsipuedes, Três Cruzes e Arroyo Malo no Uruguai, além de casas na Corte (Rio de Janeiro), terrenos no centro de Pelotas, inúmeras jóias, semoventes, letras e títulos. ${ }^{11}$ Dividida em duas partes iguais, a herança que coube a Amélia girou em torno de 558:709\$849 réis enquanto a outra parte foi dividida igualmente entre os oito filhos. Desta forma, o patrimônio legado invariavelmente garantiria o sustento da família sem maiores problemas.

Com a intenção de resguardar este patrimônio, Aníbal lança mão de uma prática que, de acordo com Denise Ognibeni, ${ }^{12}$ era bastante comum entre 0 núcleo charqueador da região. Em seu testamento, ele estabelece cláusulas que visavam impedir a dilapidação dos bens, pelos futuros maridos de suas filhas. Passado aproximadamente um ano e meio da morte do patriarca da família, a segunda filha mais velha, Izabel Hartley Maciel, se casa com o médico Tancredo Francisco de Sá enquanto a filha primogênita, Sinhá, casa-se somente em 1890, passando a residir na casa que pertencia aos pais. Sinhá uniu-se em matrimônio com o primo Lourival Antunes Maciel, filho do tenente coronel Eliseu Antunes Maciel. ${ }^{13}$

As cartas de Amélia, em sua maioria, foram remetidas a esta filha, Sinhá, que ao permanecer na casa, assumiu o papel de arquivista da memória, nos levando a crer que as missivas recebidas nunca deixaram a residência, o

9 Vários charqueadores e estancieiros pelotenses obtiveram títulos de nobreza neste momento, alguns devido a esta atitude. Silvia Moraes utilizando como critério a naturalidade, fixação ou residência na cidade e/ou desenvolvimento de atividades econômicas permanentes no município, encontrou 17 titulares o que considerou um número bastante significativo já que Pelotas era considerada uma cidade de porte médio em termos demográficos. Entretanto, seu trabalho não aponta os motivos pelos quais foram concedidos os títulos. MORAES, Silvia Beatriz Pierebom. Os casamentos entre descendentes de nobres pelotenses na segunda metade do século XIX. Pelotas, UFPel, 1997, p.9. (História, Monografia de conclusão do curso de Licenciatura).

10 CARVALHO, Mario Teixeira de. Nobiliário Sul-Riograndense, p.336.

11 Arquivo Público do Estado do Rio Grande do Sul. (APERGS). Inventario do Barão de Três Serros. n.1071, Maço 60, Estante 25 , Ano $1887,1^{\circ}$ Cartório de Orphãos e Provedoria.

12 OGNIBENI, Denise. Charqueadas pelotenses no século XIX: cotidiano, estabilidade e movimento. Pelotas, PUCRS, 2005. (História, Tese de doutorado).

13 OGNIBENI, ao estudar as estratégias de manutenção dos bens por parte dos charqueadores, conclui que as mulheres, através do casamento com indivíduos de sua própria família como de outra, garantiam os elos que ligavam os bens e os interesses do grupo charqueador. OGNIBENI, Denise. Charqueadas Pelotenses no século $X I X$, p.230. 
que garantiu que fossem preservadas. ${ }^{14} \mathrm{O}$ fato de a casa ter se mantido como propriedade da família durante três gerações, antes de ser entregue ao poder público municipal - com a finalidade de se transformar em Museu -, também deve ser levado em conta, pois como expõe Chartier, o material dado ao historiador grava a sucessão de gestos, que de geração em geração, constituíram uma parte de todas as cartas escritas e recebidas em testemunho da identidade familiar. ${ }^{15}$

As viagens de Amélia e de sua família para o Rio de Janeiro eram sempre noticiadas nas colunas sociais dos jornais pelotenses:

Partidas

Para o Rio Grande, afim de tomarem o Itassucê que os conduzirá ao Rio, seguiram hoje a exma. baroneza dos Três Serros e o illustrado médico sr. dr. Tancredo de Sá com sua exma. família. Ao bota fora dos distinctos viajantes compareceram muitas exmas. famílias e cavalheiros. ${ }^{16}$

Entretanto, o cortejo familiar, como as cartas evidenciam, não viajava sozinho, fazia-se acompanhar por empregados como copeiros, amas-de-leite e demais criados, sendo que alguns permaneceriam no Rio de Janeiro servindo Amélia. Desta forma, como coloca Perrot, possuir criados é a forma mais visível de pertencer a uma casta superior, a das "pessoas servidas" que podem dedicar seu tempo livre à representação e a ostentação do luxo. ${ }^{17}$

Amélia relata que o ato de escrever cartas para a filha investia-se de um significado especial: "me parece, que estou conversando comtigo", 18 "Basta de prósa, não?"19 Ela deixa evidente - e de forma recorrente nas cartas - seu propósito de "entabular conversa", o que acaba determinando o "tom" que suas linhas adquiriam, de uma escrita solta que priorizava assuntos que ela considerava importantes. Isto, no entanto, não a impedia de tocar em amenidades que, segundo ela, não deveriam ocupar espaço nas missivas: “Espraei-me mais n'este assumpto, minha querida filha, para conversar mais tempo

14 Como lembram Dauphin e Poublan, a ocupação de vastas residências facilitou o processo de arquivamento de documentos familiares. DAUPHIN, Cécile; POUBLAN, Daniele. Maneiras de escrever, maneiras de viver: cartas familiares no século XIX. In: Destinos das letras: história, educação e escrita epistolar. Passo Fundo: UPF, 2002, p.75-87.

15 CHARTIER, Roger. Préface. In: DAUPHIN, Cécile; LEBRUN-PÉZERAT, Pierrette e POUBLAN, Danièle. Ces bonnes lettres: une correspondence familiale au XIXe siécle. Tradução livre de Jair F. Dupont. Paris: Albin Michel, 1995, p.13.

16 A opinião Publica. Pelotas, n.112, p.03 de 18 de maio de 1917.

17 PERROT, Michelle. Figuras e papéis. In: PERROT, Michelle. (org.). História da vida privada 4: Da Revolução Francesa à Primeira Guerra. São Paulo: Companhia das Letras, 1991, p.178.

18 Carta da Baronesa. Rio de Janeiro, 10 de julho de 1909.

19 Carta da Baronesa. Rio de Janeiro, 06 de junho de 1917. 
comtigo". ${ }^{20}$ Por vezes, a consciência de que narrava detalhadamente os acontecimentos, levavam-na a pedir à filha: "Não te aborreças, por estar eu a tomar-te o tempo, com essas banalidades, pois o faço, por me parecer, que estamos juntas, conversando". ${ }^{21}$

Isto sugere que Amélia percebia o ato de escrever cartas como uma tarefa prazerosa - que se assemelhava a uma conversa - e que, por isso, alguns assuntos - mais aborrecidos - podiam ou deveriam ser deixados para o momento do encontro entre as duas. Quando considerava que alguns assuntos eram delicados - ou de ordem privada - e que deveriam ser comentados apenas com a filha, Amélia deixava isto muito claro: "e aqui para nós", 22 "estas cousas, são só para ti". ${ }^{23}$

As cartas de Amélia não seguem um padrão rígido, algumas possuem a letra mais trabalhada, o que poderia denotar um maior tempo reservado à sua feitura, outras, porém precisavam ser acabadas ou enviadas rapidamente em função da urgência, da existência de um portador, etc. Há também aquelas em que uma última lembrança e a falta de espaço na carta fazem com que ela escreva em algum cantinho da folha, ou então na vertical sobre o próprio texto. A separação dos assuntos é feita através de um maior distanciamento entre as frases sem recorrer a uma nova linha, o que desperdiçaria o papel e tornaria volumosa a carta. Sua escrita é bem pontuada, com destaque para o reiterado uso de vírgulas, que pausam constantemente o texto. Sublinhava as palavras para salientar e utilizava-se, com freqüência, de observações finais.

Constata-se que ela procurava não perder as oportunidades de enviar ao menos algumas linhas à filha, como nesta carta em que ela nos revela que "Estou escrevendo ás carreiras, porque tenho $\mathrm{mt}^{\circ}$. que fazer, e o tempo não chega", ${ }^{24}$ "eu estou de carro na porta $\mathrm{p}^{\mathrm{a}}$ ir ao Cemitério". ${ }^{25}$ Algumas cartas são respondidas tão logo recebidas: "Acabo de receber tua segunda cartinha", ${ }^{26}$ outras recebidas enquanto escreve, "Parei esta, para lêr tua carta de 29 do passado, que n'este momento acabo de receber, e aprésso-me a responder". ${ }^{27}$ mas há, também, cartas curtas, verdadeiros bilhetes e, ainda, outras que são escritas com o objetivo de complementar cartas anteriores: "esta será pois um complemento da outra". ${ }^{28}$

\footnotetext{
20 Carta da Baronesa. Rio de Janeiro, 12 de janeiro de 1910. Sua carta neste dia continha oito laudas.

21 Carta da Baronesa. Pelotas, 28 de agosto de 1916.

22 Carta da Baronesa. Rio de Janeiro, 14 de julho de 1909.

23 Carta da Baronesa. Rio de Janeiro, 14 de julho de 1909.

24 Carta da Baronesa. Pelotas, 09 de setembro de 1916.

25 Carta da Baronesa. Rio de Janeiro, 06 de outubro de 1899.

26 Carta da Baronesa. Rio de Janeiro, 22 de julho de 1899.

27 Carta da Baronesa. Pelotas, 12 de julho de 1916.

28 Carta da Baronesa. Rio de Janeiro, 06 de maio de 1909.
} 
Através de uma de suas cartas, descobrimos que não costumava fazer cópias das cartas que enviava à família, "para escrever a Vocês, nunca faço copia". ${ }^{29}$ Da mesma forma, em um de seus vários "P. S." conta que nem sempre passava a limpo, "Não me animei a passar esta a limpo, portanto adivinha o que não entenderes"..$^{30}$ Uma eventual passagem a limpo poderia melhorar a letra e tornar a carta mais bonita, tal como recomendavam as regras epistolares, mas também poderia acarretar alterações no texto. Esta escrita íntima, entre mãe e filha, caracterizada por uma linguagem muito próxima à coloquial permitia, de acordo com a própria Amélia, um maior desleixo, já que ela não suspendia o envio da carta, apesar de entender que esta necessitava ter sido refeita.

Entretanto, ela reconhecia que, por vezes, as suas cartas feriam os padrões de organização textual, parecendo-se mais com as cartas que uma de suas criadas enviaria. Mesmo assim, enviava a carta à filha, acrescentando, ao final, uma justificativa enternecedora,

esta carta está nas condicções da Véva [criada], mas tu não deixes ninguem lêr, e advinhando os garranchos, vai dividindo os assunptos, cuja importancia, revéla somente, o desejo que tem uma mãe auzente, de conversar com uma filha tão querida, como tu. ${ }^{31}$

O início de suas cartas tende a respeitar um padrão, começando pela resposta aos assuntos abordados: “Creio ter respondido á todos os tópicos de tua carta". ${ }^{32}$ Este padrão nos remete a uma leitura implícita das cartas de Sinhá, a partir das cartas de Amélia, podendo nos revelar muito sobre o que Sinhá lhe escrevia e a interpretação dada por Amélia ao tom dessa escrita: "N'ella te mostras aprehensivel pela minha estada aqui; mas não tenhas cuidado". ${ }^{33}$

O fato de Amélia não ter entendido algum comentário feito por Sinhá, como, por exemplo, em relação ao livro Abaixo as armas! nos remete à maneira como ela realizava a leitura das cartas. Ela escreve à filha, dizendo que não havia compreendido, "apezar de nunca lêr as tuas cartas, ás préssas, mas ao contrario, as relêr $\mathrm{mt} .{ }^{\text {as }}$ vezes.". ${ }^{34}$ Esta leitura - feita repetidamente e com vagar - evidencia o tempo gasto por ela investido no "pacto epistolar" e que envolvia o recebimento, a leitura, a resposta e o armazenamento das cartas. ${ }^{35}$

29 Carta da Baronesa. Curitiba, 06 de setembro de 1903.

30 Carta da Baronesa. Rio de Janeiro, 24 de agosto de 1899.

31 Carta da Baronesa. Rio de Janeiro, 02 de dezembro de 1899. (Grifo da Baronesa).

32 Carta da Baronesa. Rio de Janeiro, 30 de outubro de 1903.

33 Carta da Baronesa. Rio de Janeiro, 30 de outubro de 1903.

34 Carta da Baronesa. Rio de Janeiro, 28 de janeiro de 1918.

35 GOMES, Ângela de Castro. (org.). Escrita de si, escrita da História. Rio de Janeiro: Editora FGV, 2004. 
Algumas vezes, o recebimento e a leitura é por ela comentado: "Causou-me a sua leitura, grande contentamento, por vêr que gozam todos bôa saúde", ${ }^{36}$

não imaginas, o alvorôço que houve por aqui, no dia em que chegáram as tuas cartas para a gurysada! Cada qual, queria mostrar a sua primeiro, e tudo fallava ao mesmo tempo. A Wanda então decôrou toda, e dizia de vez em quando: o que eu achei mais graça, foi no elephante! Enfim, foi um contentamento geral! ${ }^{37}$

Após comentar a carta anterior da filha, a Baronesa passa a relatar o que havia feito, fornecendo notícias sobre os outros - familiares e conhecidos -, comentando uma série de temas e, é neste momento, que expressava acreditar que os seus assuntos "vão misturados". ${ }^{38}$ Podemos entender essa impressão de "mistura", a partir das próprias características das cartas, pois como coloca Gomes, elas podem - a um só tempo - ter múltiplos objetivos: informar, pedir, agradecer, perguntar, consolar, etc. ${ }^{39}$ A preocupação com a "mistura" dos assuntos - que é bastante recorrente - pode demonstrar uma dificuldade com a organização dos temas, apontando para uma característica da autora que é a de tentar compartilhar o máximo de assuntos com a filha, além de nos revelar uma constante autocrítica. Em um risco passado no final da página, ela informa à filha que "Só agora dei, pelas repetições, mas... deixa passar". ${ }^{40}$

Muito raramente Amélia se dispersava em assuntos que considerava pouco importantes. Quando isso ocorria, não deixava de revelar à filha a consciência de que estava se detendo em assuntos insignificantes, não tendo começado algo que julgava de fato mais importante, "Só agora vejo, que estou prolongando este assumpto, sem tratar dos de tua carta: passemos a elles". ${ }^{41}$ 0 assunto ao qual se refere Amélia - e no qual havia se prolongado -, consta de uma página e meia das quatro páginas da carta que ela escreveu naquele dia e que começaria, como de costume, fazendo alusão à que havia recebido da filha. ${ }^{42}$ Neste dia, Amélia comenta que uma carta remetida por Sinhá no dia 14 de Agosto havia chegado à Curitiba no dia 2 de Setembro, o que a levou

36 Carta da Baronesa. Pelotas, 12 de julho de 1916.

37 Carta da Baronesa. Rio de Janeiro, 08 de fevereiro de 1918. Amélia se encontrava com os netos, filhos de Isabel. Wanda era a caçula de cinco anos.

38 Carta da Baronesa. Rio de Janeiro, 15 de junho de 1909.

39 GOMES, Ângela de Castro. (org.). Escrita de si, escrita da História, p.19.

40 Carta da Baronesa. Rio de Janeiro, 17 de dezembro de 1917. A repetição a que Amélia se refere trata-se da afirmação - feita por duas vezes - de que a Sinhazinha Camargo estava "bem doente". Ela deve ter percebido a repetição, provavelmente, no dia seguinte, ao retomar a escrita da carta.

41 Carta da Baronesa. Curitiba, 03 de setembro de 1903.

42 Esta preocupação com uma carta muito extensa poderia ocorrer por dois motivos: o primeiro diz respeito ao cansaço que poderia causar na filha com uma leitura longa, e a segunda está ligada ao envio. De acordo com ela, uma carta muito volumosa podia atiçar a curiosidade dos carteiros. 
a comentar em tom irônico: “Já é rapidez!". ${ }^{43}$ A partir daí, segue contando para a filha sobre a prisão de um funcionário do correio que violava as cartas, apossando-se do conteúdo e vendendo os selos, não deixando de especular que isso tenha acontecido com as cartas que havia se apressado em mandar para as filhas ao chegar à cidade.

Durante a leitura de suas cartas percebe-se sua preocupação em responder a todas as cartas recebidas, "Quanto às tuas, de 2 e 5 do actual, assim como as de Talú, e Alzira, recebi-as; e logo respondi: já devem estar de pósse das respostas". ${ }^{44}$ Pode-se entender esta preocupação a partir de trechos de uma outra carta que Amélia escreve à filha. Nela, comenta ter recebido uma carta da Mercedes - em resposta a uma outra que havia enviado - e pede que a filha lhe dê o seguinte recado: "Diz á ella que não the escrevo novamente, para não forçal-a a responder-me, pois avalio o quanto não estará ella atrapalhada,com os aprestes para o casamento". ${ }^{45}$

Este recado de Amélia nos revela uma praxe. Nenhuma carta deveria ficar sem resposta, mesmo que, por vezes, a resposta demorasse, "Mais vale tarde, que nunca; dirá com certeza a Prima, e como eu sou da mesma opinião, não quiz apezar de tarde, deixar de cumprir o meu dever". ${ }^{46}$

A única carta de Sinhá existente no acervo do Museu nos fornece um indício consistente de que Amélia costumava, após ler e responder às cartas que recebia, anotar em cada uma delas que estava "Respondida". ${ }^{47}$ Esta anotação nos exemplifica uma forma particular de organização da correspondência recebida. Talvez por não manter o hábito de fazer cópia de suas cartas respostas, ou mesmo por medo de confiar à memória a tarefa de lembrar-se de ter escrito, ela opte por registrar. Além da carta de Sinhá, uma outra carta remetida pelo filho Aníbal, no ano de 1890 , nos oferece a possibilidade de identificar outras "marcas subjetivas" feitas por Amélia. Na última página da carta, junto às despedidas e com marcas de dobras, lê-se: "Do meu querido filho". ${ }^{48}$ Pode-se supor, pelas marcas que o papel apresenta, mais desgastado na parte da anotação feita no canto superior esquerdo, que, ao remexer nas cartas guardadas, Amélia identificasse o remetente antes mesmo de abrir a carta. Entretanto, se Amélia procurava certificar-se de ter respondido as cartas que

43 Carta da Baronesa. Curitiba, 03 de setembro de 1903. (Grifo da Baronesa).

44 Carta da Baronesa. Curitiba, 03 de setembro de 1903. Talú (Isabel) e Alzira são irmãs de Sinhá.

45 Carta da Baronesa. Rio de Janeiro, $1^{\circ}$ de julho de 1909.

46 Carta da Baronesa. Pelotas, 04 de julho de 1885. (Grifo nosso).

47 Carta de Sinhá. Pelotas, 08 de abril de 1897. Esta anotação feita na vertical na última página da carta possui muitas semelhanças com a letra da Baronesa. Além disso, a neta Zilda, possivelmente, ao entregar a carta ao Museu dentro de um envelope tenha nele escrito: "Carta da mamãe à vovó, em 08 de abril de 1897, notar, no canto, a anotação feita pela vovó: 'Respondida'.'

48 Carta de Aníbal, filho da Baronesa. Porto Alegre, 28 de novembro de 1890. 
The eram enviadas, Sinhá, por sua vez, era a guardiã das que recebia de sua mãe. A filha, raras vezes, deixa suas "marcas" nas cartas recebidas da mãe. Feitas logo abaixo da data ou do vocativo se lê, em tinta azul: "Respondida"49 ou mais frequentemente " $R$ ".

Sinhá não guardava somente as cartas enviadas para sua casa em Pelotas, mas também, as remetidas de Pelotas para o Rio de Janeiro, como podemos comprovar através da correspondência de 1916. Desta forma, as dezesseis cartas daquele ano viajaram para o Rio e voltaram nas malas de Sinhá, para o lugar onde haviam sido escritas.

Em relação ao lugar usado por Amélia para responder às cartas, raramente é mencionado, mas pode-se inferir que, na maioria das vezes, escrevia no quarto, fosse ele do hotel em que estava hospedada ou da casa que estava alugando, "Estou te escrevendo do quarto da Zilda, do qual faço o meu refugio. Aqui só eu entro"..$^{50}$ Este lugar tranqüilo permitia uma maior concentração para a escrita de alguém que, como ela mesma menciona, escreve à medida que se lembra das coisas, exigindo toda a atenção da filha, "Pôe a tua prespicacia á próva, para decifrares estes garanchos, e botar em ordem os assumptos, pois vou escrevendo á proporção que vou me lembrando; d'ahi, essa barafunda", ${ }^{51}$ justificativa que aparece também no meio do texto, encerrada em um parêntese: "(não repares, os assumptos estarem misturados, mas escrevo, á proporção que me lembro, pois do contrario, ficaria mt. ${ }^{a}$ cousa por dizer)". ${ }^{52}$ Poucas, também, são as vezes em que Amélia nos revela as condições em que está escrevendo ou o exato momento de sua escrita, o que não impede de valorizarmos ainda mais sua dedicação à tarefa: "Estou escrevendo em cima da janella e com a penna amarrada na caneta, já vês com que difficuldade o estou fazendo". ${ }^{53}$ As dificuldades aqui relatadas e o tempo extraído da rotina para "pegar na pena" ofereciam seus "riscos", como pôde comprovar Sinhá, segundo as palavras de Amélia:

Imagino o teu aborrecimento, ao vêr o tinteiro entornado sobre a carta que estavas terminando, inutilisando assim, um trabalho feito, com sacrificio de tempo. Felismente, não és supersticiosa, porque então, já vias n'isso, um máo agouro. $^{54}$

49 Carta da Baronesa. Rio de Janeiro, 19 de junho de 1917. Após a inscrição "Respondida", Sinhá fez uma soma de valores em dinheiro.

50 Carta da Baronesa. Rio de Janeiro, 06 de junho de 1917. (Grifo da Baronesa).

51 Carta da Baronesa. Rio de Janeiro, 23 de agosto de 1909. Provavelmente, Amélia inverteu por engano as letras na palavra perspicácia assim como esqueceu de um " $r$ " na palavra garranchos.

52 Carta da Baronesa. Rio de Janeiro, 14 de setembro de 1917.

53 Carta da Baronesa. São Domingos, 20 de setembro de 1900.

54 Carta da Baronesa. Rio de Janeiro, 07 de maio de 1918. 
Amélia se queixava, algumas vezes, de problemas nos olhos que prejudicavam a sua escrita, "Já estou com os olhos a me arder, por isso nao vou alêm". ${ }^{55}$ "Não sei si intenderás esta, pois estou com um terçol, que me tira a vista", ${ }^{56}$ que a levavam a interromper a escrita: "Como ando mal dos olhos, penso passar uns 8 dias sem escrever, a vêr si melhoro; por isso não estranhes a falta de cartas minhas". ${ }^{57}$ Deve ter sido por esta razão - exigir menos dos olhos -, que Amélia preferia escrever sob a luz do dia: “Quiz escrever-te de dia, mas não tive tempo, e agora á noite, só pude fazêl-o a esta hora [23 horas], porque a ultima visita, sahiu á pouco". ${ }^{58} \mathrm{Em}$ várias passagens, nos revela que escrevia pela manhã: "Vou já vestir-me, para ir vêl-a. (são 8 horas da manhã)", 59 "Escrevo-te, lembrando-me que talvez a esta hora (10 da manhã) estejas", 60 ou pelo menos, começava, "Parei de escrever, para ir almoçar, e n'essa occasião, chegou o teleg. ${ }^{\text {ma }}$ da Zilda ". ${ }^{61}$

Quando esteve em Pelotas, em 1916, o frio que limitava seus passeios e visitas, também é apontado como um forte empecilho para a escrita: "Eu tenho as mãos geladas, e estou te escrevendo com mt. ${ }^{a}$ difficuldade". ${ }^{62}$ Esta dificuldade obrigava Amélia a fazer uma pausa na tarefa, ou até mesmo a terminá-la: "Estamos a 28, porque hontem o frio não me deixou terminar esta, e agora mesmo, me priva de continuar", 63 "Vou terminar esta porque estou nos meus máus dias para escrever; é um errar constante, o que mt. ${ }^{\circ}$ me aborrece. Fica o résto para outra vez". ${ }^{64}$

Ao contrário do que poderíamos supor, de que somente após a viuvez - com mais tempo para si e distante da família - Amélia teria começado a escrever, encontramos registros desta prática já no ano de $1885 .{ }^{65} \mathrm{O}$ cultivado hábito de escrever pode ser constatado na troca de cartas que mantinha com

55 Carta da Baronesa. Rio de Janeiro, 26 de maio de 1909.

56 Carta da Baronesa. Rio de Janeiro, 28 de abril de 1909.

57 Carta da Baronesa. Rio de Janeiro, 12 de outubro de 1909. Amélia, provavelmente, interrompeu a escrita por mais de oito dias, já que a próxima carta que localizamos data do dia 25 de outubro e ela não faz referência à escrita de outras cartas neste período.

58 Carta da Baronesa. Rio de Janeiro, 24 de junho de 1909.

59 Carta da Baronesa. Rio de Janeiro, 23 de abril de 1909. Referia-se a uma casa para alugar.

60 Carta da Baronesa. Rio de Janeiro, 04 de setembro de 1917.

61 Carta da Baronesa. Rio de Janeiro, 26 de junho de 1917. Zilda era uma de suas netas, filha de Sinhá, que enviava telegrama pedindo à avó que comprasse dois pares de luvas de camurça.

62 Carta da Baronesa. Pelotas, 27 de julho de 1916.

63 Carta da Baronesa. Pelotas, 27 de julho de 1916.

64 Carta da Baronesa. Pelotas, 07 de outubro de 1916.

65 Para escrever, Amélia, com certeza, escolhia o tinteiro de sua preferência dentre os três disponíveis na casa, informação a que tivemos acesso ao consultar o inventário do Barão de Três Serros. Nele descobrimos um com castiçal avaliado em cem mil réis $(100 \$ 000)$ e dois outros pequenos avaliados em noventa mil réis $(90 \$ 000)$. Arquivo Público do Estado do Rio Grande do Sul. Inventário do Barão de Três Serros, n.1071, maço 60, estante 25, ano 1887. $1^{\circ}$ Cartório de Orphãos e Provedoria, p.51. 
uma prima. Em duas destas cartas, Amélia nos revela que já havia escrito outras duas à prima: "Como não tive ainda contestação das duas cartas que lhe dirigi, receio não tenhão ellas chegado a seu destino, o que bastante me contraria". ${ }^{66}$ Estas cartas, porém, apresentam significativas diferenças em relação às cartas que enviaria, posteriormente, à filha Sinhá.

Em folhas de papel - com delicado adorno no canto superior esquerdo e com letra impecável - ela trata dos assuntos de forma bastante organizada. $\mathrm{Na}$ carta de 4 de julho, ela expressa - já nas primeiras linhas - o objetivo da carta, que era o de agradecer a remessa das encomendas por ela feitas à prima, e de informar que estava tudo do seu agrado. Na seqüência, comenta que, através do Eliseu, havia sabido das recepções que a prima tinha oferecido e pelas quais a felicitava. A seguir, fala, brevemente, sobre a saúde dos familiares, arrematando a carta com uma despedida que reafirmava a amizade: "Prima e amiga muito grata". ${ }^{67}$

Assim como a mãe, Sinhá também desenvolveu o hábito e costumava escrever bastante, pois como refere Amélia: "Tenho 3 cartas tuas a responder, sendo a primeira de 5 , e as outras recebidas hontem à noite do Paulino recebi de 16, e 17 do actual". ${ }^{68}$ No ano de 1899, por exemplo, Amélia remete doze cartas à filha e faz alusão a outras doze recebidas. Temos assim, bem evidenciada, uma das condições necessárias à produção e à troca de cartas: "sujeitos que se revezam, ocupando os mesmos papéis através do tempo". ${ }^{69}$

Estes aspectos mais informativos sobre a periodicidade das cartas são, sem dúvida, de extrema importância para localizarmos e datarmos o diálogo mantido entre elas e detectarmos possíveis interrupções e demoras, como através dessa referência: "Com certeza deixastes de receber alguma carta minha, pois apesar de minha falta de memoria, lembra-me bem te ter mandado contar". ${ }^{70}$ Para Amélia, no entanto, o controle que mantinha sobre quais cartas estava respondendo servia para que revelasse alguma falha ou atraso na entrega das cartas: "quero crer que haja alguma outra carta tua, antes d'ésta, e depois da de 10, que foi a ultima que me veio ás mãos", ${ }^{71}$ bem como para criticar - o que fazia constantemente - o serviço prestado

66 Carta da Baronesa. Pelotas, 10 de maio de 1885. Devido à freqüência com que a menção às cartas trocadas com a "prima Chiquinha" aparece nas cartas enviadas à Sinhá, podemos pensar que era ela a prima para quem Amélia escrevia em 1885.

67 Carta da Baronesa. Pelotas, 04 de julho de 1885.

68 Carta da Baronesa. Rio de Janeiro, 24 de novembro de 1899.

69 GOMES, Ângela de Castro. (org.) Escrita de si, escrita da História, p.19.

70 Carta da Baronesa. Rio de Janeiro, 20 de dezembro de 1899.

71 Carta da Baronesa. Rio de Janeiro, $1^{\circ}$ de fevereiro de 1910. 
pelos correios: “A tua carta de 12, em que me fallas, na de 14, ainda cá não chegou. Mudaria de rumo? É possivel, graças ao nosso correio!". ${ }^{72}$

Este hábito de escrever cartas era mantido também com as outras filhas, embora as cartas trocadas com Sinhá pareçam ter se dado em maior número. Através delas, percebemos que diante da ausência de cartas das irmãs, era Sinhá quem fornecia notícias sobre os familiares e achegados: "Esta, [Alzira] bem poucas vezes escreve, assim é, que só por tuas cartas, tenho notícias d'ella". ${ }^{73}$ As queixas pela ausência de cartas de parte das outras filhas era compartilhada com Sinhá e o comentário assumia, na maioria das vezes, um tom de indignação: “Da Talú, ainda não recebi uma só carta, n’estes 2 mezes, que aqui estou". ${ }^{74} \mathrm{Em}$ outros momentos, em uma nota curta e irônica, ela expressava seu descontentamento: "Diz á Talú, que eu ainda vivo!"75 Porém, a reprimenda pela falta de cartas também era dirigida à Sinhá. Em junho de 1909, Amélia estava há quase um mês sem receber cartas da filha. A primeira linha da carta expressava um lamento: "Os vapôres se succédem, e nem uma cartinha tua!"76 Amélia começa então a levantar hipóteses para essa incomum ausência. ${ }^{77}$ A primeira delas, e a que mais a preocupava, estava relacionada à saúde: "Estarás doente, ou alguns dos teus?"78 Chega a cogitar que a filha estivesse muito ocupada ou, então, e muito provavelmente, que a falta de cartas se devesse ao péssimo serviço do correio. Uma semana depois, Amélia veria esclarecida a ausência das cartas,

vejo o que me dizes, sobre a demóra de minhas cartas, o que justamente tem acontecido com as tuas, pois a ultima que recebi, antes d'esta, foi de 3 de Maio! [...] Nas cartas que citas, não está a minha de 4. Evapôrar-se-hia? Alëm d'essas, escrevi-te tambem a 15, 20, e 26, (mais ou menos) do passado, que já devem estar em teu poder, si não seguiram outro rumo, no caminho, fazendo o mesmo, que, as que me dizes ter escripto! ${ }^{79}$

Este registro - em que ela informa as datas de três cartas enviadas - nos fornece dado relevante sobre a freqüência com que se dava a atividade epistolar. Das 151 cartas escritas por Amélia, uma delas tem como destinatários

72 Carta da Baronesa. Rio de Janeiro, 26 de novembro de 1909.

73 Carta da Baronesa. Rio de Janeiro, 06 de outubro de 1899.

74 Carta da Baronesa. Rio de Janeiro, 08 de junho de 1909.

75 Carta da Baronesa. Rio de Janeiro. Rio de Janeiro, 30 de outubro de 1903. Segunda carta remetida neste dia.

76 Carta da Baronesa. Rio de Janeiro, $1^{\circ}$ de junho de 1909.

77 Ela comenta: "Sei perfeitamente, que não deixas de escrever, mas, é uma eternidade, para as cartas chegarem aqui." Carta da Baronesa. Rio de Janeiro, 24 de fevereiro de 1910.

78 Carta da Baronesa. Rio de Janeiro, $1^{\circ}$ de junho de 1909.

79 Carta da Baronesa. Rio de Janeiro, 08 de junho de 1909. 
a filha e o genro juntos e duas outras foram endereçadas exclusivamente ao genro. Somam-se a estas, uma carta enviada por Sinhá à sua mãe no ano de 1897 e duas outras enviadas por Amélia a uma prima no ano de 1885.

As cartas obedecem a um ritmo descontínuo e cíclico que é estabelecido pelos missivistas, podendo ser alterado, em função da distância que separava remetente e destinatário, do momento de vida de cada um deles e de acontecimentos externos: ${ }^{80}$ "Esta foi começada às 9 da manhã, e já tive que interrompel - a, para receber a visita da Leonidia, e da Clarinha Paiva". ${ }^{81}$ chegando algumas vezes a retardar o envio.

Escrevi-te a 4, mas infelismente devido a mt. as interrupções que tive, só hontem pude terminal-a, e isso mesmo, já sem tempo de alcançar o vapôr que n'esse dia partio para ahi: esta será pois um complemento da outra. ${ }^{82}$

$\mathrm{O}$ ato de escrever uma carta, como se pode constatar nestes trechos, dependia do atendimento de algumas condições que poderíamos denominar de ordem material, e outras de ordem psicológica. Momentos de tristeza profunda tornavam difícil a tarefa da escrevente, como se depreende dessa passagem: "Tu porem, não terás extranhado essa, falta, por que bem avalias, o quanto me é doloroso, o assumpto d'ellas". ${ }^{83}$ Esta pausa na escrita nos revela a forma como Amélia lidava com seus sentimentos, pois ao escrever para Sinhá, teria que, além de narrar os últimos acontecimentos, tocar no falecimento de sua filha Dulce. Recolhida em sua dor e sem coragem para responder as cartas de Sinhá e de outras pessoas que tinham lhe escrito em solidariedade, Amélia escreveria à filha somente dezesseis dias depois.

As cartas endereçadas à Sinhá começam no mês de abril de 1899 e se estendem até o mês de setembro de 1918. O maior fluxo de cartas enviadas se concentra no ano de 1909, ano em que a filha não pôde viajar para o Rio de Janeiro. As cartas deste ano começam a ser remetidas no dia 23 de abril, poucos dias depois de sua chegada ao Rio de Janeiro, ${ }^{84}$ e cessam na véspera do Natal. Entretanto, não devemos tomar como parâmetro o término do ano para entender a dinâmica das cartas. Amélia seguiria escrevendo - mesmo durante os feriados do final do ano -, aguardando ansiosamente que Sinhá viajasse para o Rio de Janeiro, o que aconteceria apenas em princípios de abril

80 GOMES, Ângela de Castro.(org.) Escrita de si, escrita da História, p.20.

81 Carta da Baronesa. Pelotas, 30 de setembro de 1916. Ao retomar a carta, Amélia agregaria informações obtidas com as visitas que recebera.

82 Carta da Baronesa. Rio de Janeiro, 06 de maio de 1909.

83 Carta da Baronesa. Rio de Janeiro, 22 de julho de 1899.

84 Em sua carta de 09 de setembro de 1909. Amélia nos informa que havia deixado Pelotas quando Déa, sua neta, tinha dois meses. Considerando que Déa nasceu no dia 10 de fevereiro daquele ano, deduz-se que Amélia partiu por volta de 10 de abril. 
de 1910. No período compreendido entre 23 de abril de 1909 e 30 de março de 1910 - pouco mais de 11 meses -, em que as duas não puderam se encontrar pessoalmente, foram escritas sessenta e uma cartas, do que se deduz que mais de uma carta foi escrita por semana.

Outros aspectos reveladores da dinâmica da prática epistolar dizem respeito ao ritual que abrangia a escrita das cartas e o tempo de espera, a ansiedade que envolvia aguardar pelo correio, expressa já nas primeiras linhas: "Recebi ante - hontem, tua carta de 14 do corrente, já anciosamente esperada: quanto á de 9 , ainda está em viagem". ${ }^{85}$

Enviar cartas implicava tempo gasto, não só na leitura da carta recebida e na escrita de uma outra, em resposta àquela. Pressupunha saber os horários de funcionamento do correio, de chegada e partida de vapores responsáveis por fazer estas chegarem ao seu destino. Além disso, as cartas de Amélia e Sinhá, muitas vezes, não viajavam sozinhas, seguiam na companhia de presentinhos que precisavam ser remetidos por portadores confiáveis. Uma série de lembrancinhas e encomendas eram costumeiramente enviadas junto com outras cartas para familiares. Por vezes, eram remetidas por conhecidos que se constituíam em "cartas vivas", mas que, nem por isso, faziam Amélia abrir mão de enviar algumas linhas. Sabe-se que as notícias detalhadas costumavam serem informadas através de cartas, enquanto as mais breves eram enviadas através de telegramas utilizados, quase sempre, em situações que demandavam urgência. ${ }^{86}$

A dedicação semanal à prática e a seriedade com que Amélia encarava a leitura e a escrita de cartas parece justificar a cobrança que fazia às filhas. Afinal, o pacto epistolar se mantinha através da troca de informações e de notícias, e implicava num "dever de resposta" para estas "conversas" à distância.

Desta forma, ao utilizar as correspondências para se comunicar com a filha e estreitar os laços familiares, a Baronesa nos fornece pistas sobre a escrita e a leitura de cartas na virada do século XX. O hábito de escrever cartas, ao mesmo tempo em que obedece a determinados padrões textuais formais, também nos possibilita apreender as particularidades de escrevente e destinatário impressas na missiva. Ao servir como suporte de inúmeros assuntos, elas podem revelar marcas de como foram armazenadas e organizadas por seus destinatários.

85 Carta da Baronesa. Rio de Janeiro, 24 de fevereiro de 1910. (Grifo da Baronesa).

86 O jornal Diário Popular de Pelotas de 1916 possui um quadro especificando os valores dos telégrafos e correios. Consta sobre as taxas telegráficas que a tarifa por palavra para o interior da União variava de local para local sendo que entre Rio Grande do Sul e Rio de Janeiro custava 300 réis. O serviço interno tinha ainda a taxa de 600 réis por telegrama, pagando 200 réis dentro de dois ou três estados. O correio era a forma mais barata já que as "cartas ordinárias" custavam "100 réis dentro do território da República e 200 réis para o exterior, por 15 gramas ou fração.” Diário Popular. Pelotas, n.10, p.06, 13 de janeiro de 1916. 
As cartas de Amélia nos fornecem com riqueza de detalhes o clima epistolar que envolve a espera, o recebimento, o instante da escrita e o envio ao destinatário. Referem as condições e momentos em que Amélia escreve, o que, algumas vezes, por sua dificuldade, confere ainda mais valor às missivas. Sendo assim, as correspondências demandavam das duas escreventes tempo para leitura e escrita, assinalando o ritmo descontínuo e cíclico das trocas epistolares. Ao perfazerem o pacto epistolar, mãe e filha indicam como se estabeleciam as comunicações no início do século XX; sinalizam para as formas de escrita e leitura e, como estas eram percebidas pelos indivíduos que se revezavam ora como remetentes, ora como destinatários. Além disso, por sua particularidade, lançam luz sobre as nuances do modo de vida familiar de um grupo abastado do início do século. 